\title{
Experimental study and comparative numerical modeling of creep behavior of white oak wood with various distributions of earlywood vessel belt
}

\author{
Junfeng Hou, Yingqiu Jiang, Yeqiao Yin, Weigang Zhang, Haili Chen, Youming Yu* ${ }^{*}$ and Zhihong Jiang*
}

\begin{abstract}
Many researches have been conducted to investigate creep behavior of wood; however, the effects of structure on wood creep behavior remain unclear. Therefore, the effects of existence and distribution of earlywood vessel belt on creep behavior of white oak (Quercus alba L.) wood were investigated by dynamic thermal mechanical analyzer (DMA) with double cantilever bending in this study. Besides, a comparative numerical modeling simulation on strain curves of white oak specimens was completed using Burger and Five-parameter model. Results revealed that instantaneous strain and 45-min strain of specimens decreased with increase in the distance between earlywood vessel belt and stress acting surface obviously. Additionally, instantaneous strain and 45-min strain of specimens remarkably increased with increase in temperature from 20 to $80^{\circ} \mathrm{C}$. An obvious bending creep behavior was observed with increase in temperature from 20 to $80^{\circ} \mathrm{C}$. Both Burger and Five-parameter model can effectively simulate the creep behavior of white oak specimens with $R^{2}$ values greater than 0.90 . Furthermore, Five-parameter model illustrated a better fitting effect than Burger model in the final creep stage due to the introduction of a non-linear creep strain growth expression. It concluded that creep behavior of white oak wood strongly depends on the existence and distribution of earlywood vessel belt.
\end{abstract}

Keywords: White oak (Quercus alba L.), Earlywood vessel belt, Bending creep behavior, Multivariate linear fitting, Comparative numerical modeling

\section{Introduction}

Wood, a porous, anisotropic and nonhomogeneous biopolymer of cellular structure, is classified as a viscoelastic material with mechanical properties depending on test temperature, moisture content $(\mathrm{MC})$, structure and chemical composition [1, 2]. It exhibits simple bending characteristic due to the viscoelastic behavior with porous structure [3]. Creep behavior of wood has been widely used to improve yield rate and promote the utilization of precious wood in the production process of

*Correspondence: yuyouming@zafu.edu.cn; jzh@zafu.edu.cn College of Engineering, Zhejiang Agriculture \& Forestry University, Hangzhou, Zhejiang 311300, People's Republic of China curved wood products [4], which have been widely used in the production of furniture, arched windows and doors, baskets, barrels, handicrafts, boats and ships, tool handles, agricultural implements and musical instrument [5].

As a polymer of viscoelastic materials, mechanical property of wood is strongly depended on MC, stress, temperature, treatment time and so on. It has been reported that viscous flow of wood is observed to increase with increase in external stress under the high MC condition [6]. Tensile creep of wood has also been reported to increase with increase in MC [7]. It indicated that about $70 \%$ of the cells involved in hardwood are vessel cells and wood fiber cells, and all these 
cells are longitudinally arranged in wood. Effects of vessel cells and wood fiber cells on creep performance have become an important research topic in wood processing. A great deal of research has been conducted to explore the creep characteristics of wood under the static mechanical condition $[8,9]$. Most of these researches focused on the effects of test temperature, $\mathrm{MC}$, and texture direction on creep behavior of wood $[10,11]$; however, little efforts have been found to analyze the effect of earlywood vessel belt locations on viscoelasticity and creep characteristics of ring-porous wood.

Wood is a polymer material composed of cellulose, hemicellulose, and lignin, and a natural porous polymer material composed of countless cells with different shapes, sizes, and arrangements in comparison with other polymers. Additionally, the arrangement and combination of different types of cells in space constitute wood entity. Existence of these huge numbers of cells with different shapes and sizes makes an extremely complex variable performance of physical and mechanical properties of wood in comparison with other solid materials, especially in hardwood, the cell type and arrangement are more complex and richer. As an important component of hardwood, earlywood vessel plays an extremely important role in certain hardwood such as oak (Quercus spp.), elm (Ulmus pumila), ash (Fraxinus mandshurica) and so on. A vessel is a series of axial cells that combine to form a knotless tubular structure with an infinite length. Rheological behavior of wood is closely related to factors such as $\mathrm{MC}$, temperature and external stress, and it is also closely related to the composition and arrangement of wood cells. In some cases, the latter may have a greater influence. For the annular hardwood with a great deal of earlywood vessels, the effect of earlywood vessel distribution on rheological behavior of wood cannot be ignored. Oak wood has been widely used as raw material for manufacturing flooring, furniture and wooden building beams due to its excellent bending performance and beautiful texture $[12,13]$. Many studies have been carried out to investigate the effects of chemical (i.e., polyethylene glycol) treatment, drying methods and other treatments on the creep characteristics of oak wood [14, 15], as well as the effects of texture directions on the creep characteristics of oak wood under the high temperature and humidity conditions [16-18]. More efforts have been made to investigate the mechanical behaviors of oak wood [4]. To the best of our knowledge, there has been no report of studying the effect of earlywood vessel belt on creep behavior of white oak. Therefore, it is crucial to analyze and predict the creep behavior of white oak under various distributions of earlywood vessel belt conditions.
In this study, we have systematically investigated the effects of existence and distribution of earlywood vessel belt on bending creep behavior of white oak wood by dynamic thermomechanical analyzer (DMA) under the double cantilever bending loading in the longitudinal direction at different temperatures. The distribution of earlywood vessel in the cross section of white oak specimens with various distributions of earlywood vessel belt was investigated by scanning electron microscopy (SEM) and Image-pro plus (IPP 6.0, Media Cybernetics, Inc., Rockville, USA) software. Burger model and Five-parameter model were selected further to simulate bending creep behavior of tested specimens with various distributions of earlywood vessel belt at different temperatures. This work provides valuable references for the selection of processing technology such as wood bending processing, wood drying, wood heat treatment, and wood plasticization processing technology and can also enrich the theory of wood physics and wood drying.

\section{Materials and methods \\ Experimental materials}

White oak (Quercus alba L.) lumber was obtained from Nanxun Timber Market in Huzhou city of Zhejiang Province in China. Size of tested white oak specimen was $40 \mathrm{~mm}(\mathrm{~L}) \times 12 \mathrm{~mm}(\mathrm{~W}) \times 2.2 \mathrm{~mm}(\mathrm{~T})$. Four types of specimens were prepared, as shown in Fig. 1. A is the specimen with earlywood vessel belt on the stress surface, $B$ is the specimen with earlywood vessel belt in the middle part, $C$ is the specimen with earlywood vessel belt on the back-stress surface and $\mathrm{D}$ is the control specimen.

As is well known that earlywood vessel is not evenly distributed in white oak wood, the tested specimens were carefully prepared and selected to ensure the number and distribution state of earlywood vessel in different types of specimens were relatively consistent. Structure of the end faces of tested specimens was required to be uniform and the fiber direction parallel to the four sides of tested specimens in the test process. The end, upper and lower faces of tested specimens corresponded to the cross and tangential section, respectively.

\section{Microstructure analysis and ratio of earlywood vessel belt calculation}

Distribution of earlywood vessel in the cross section of white oak specimens was investigated using a SEM (SS550, Hitachi Limited, Tokyo, Japan). Earlywood vessel belt ratio $\left(R_{\mathrm{T}}\right)$ in the cross section of Specimen A, B, C and $\mathrm{D}$ was calculated according to the thickness of earlywood vessel belt and that of the corresponding specimen from SEM image. Besides, earlywood vessel ratio $\left(R_{\mathrm{c}}\right)$ in the cross section of Specimen A, B, C and D was calculated in accordance with the area of earlywood vessel 


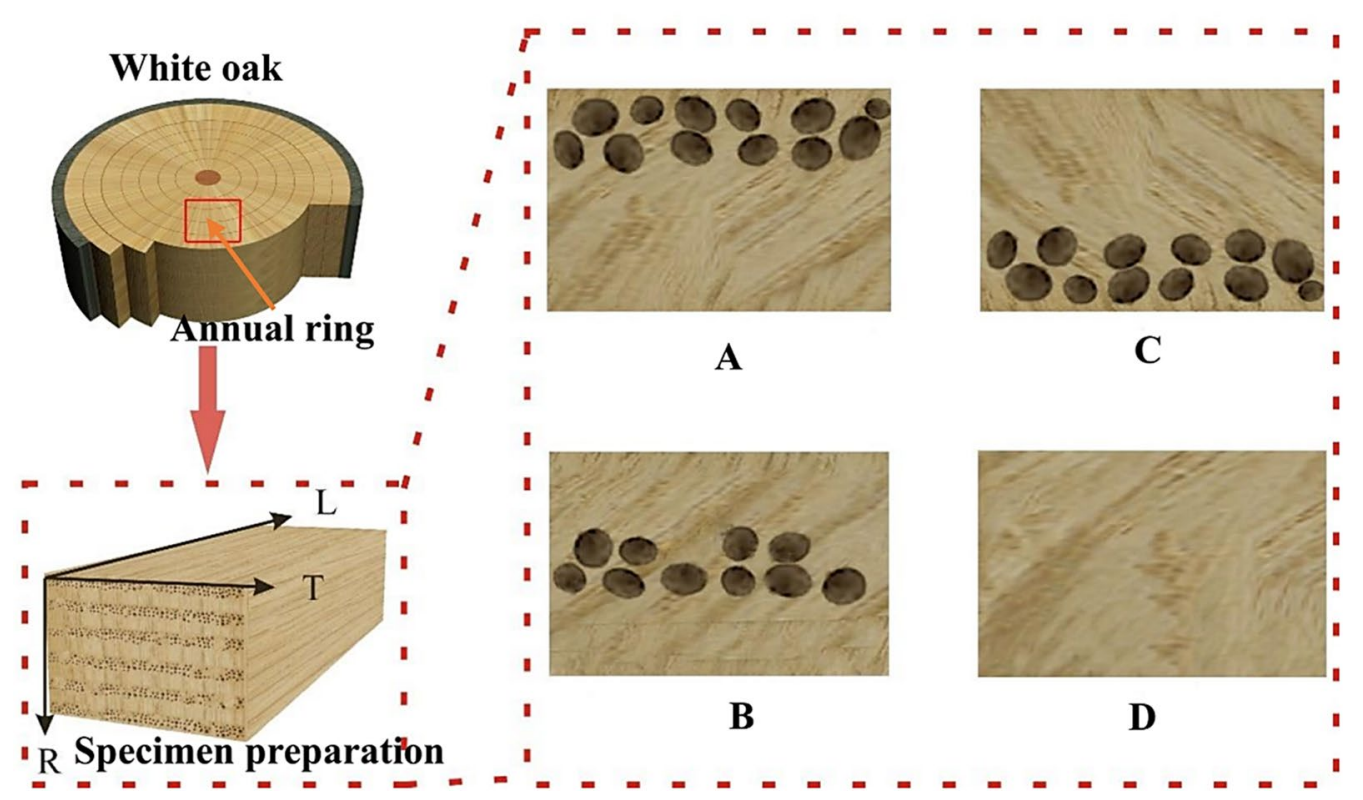

Fig. 1 Specimen preparation: Specimen A is the specimen with earlywood vessel belt on the stress surface, B is the specimen with earlywood vessel belt in the middle part, $C$ is the specimen with earlywood vessel belt on the back-stress surface and $D$ is the control specimen

cells and the area of white oak specimens in the cross section from SEM image. Twelve replicate SEM images from three adjacent repeated specimens were applied to calculate $R_{\mathrm{T}}$ and $R_{\mathrm{c}}$ for each type of white oak specimen, and the average $R_{\mathrm{T}}$ and $R_{\mathrm{c}}$ values were used for the final analysis. Thickness of earlywood vessel belt and tested specimens, area of earlywood vessel cells and tested specimens were calculated by Image-pro plus (IPP 6.0) software in this study.

\section{Experimental methods}

Creep behaviors of white oak specimens were investigated by a DMA (DMA-Q800, TA instruments, New Castle, USA) with humidity accessories under the bending loading in the longitudinal direction in this study. The adjustable range of relative humidity $(\mathrm{RH})$ is
$5 \% \sim 95 \%$, and the corresponding temperature ranged from $5{ }^{\circ} \mathrm{C}$ to $100{ }^{\circ} \mathrm{C}$. The double cantilever fixture was selected in this experiment. The creep test was conducted with double cantilever bending. The schematic diagram of double cantilever bending is presented in Fig. 2. The tested temperature applied was 20, 40, 60 and $80{ }^{\circ} \mathrm{C}$, respectively, with the corresponding $\mathrm{RH}$ of specimens controlled at $66,72,76$ and $81 \%$ to keep the MC (12 $\pm 0.1 \%)$ and dimension parameters of tested specimens consistent. The specimens were adjusted to an equilibrium state under the corresponding temperature and RH in a humidity chamber throughout the creep strain measurement process. This equilibrium state of reset temperature and $\mathrm{RH}$ was kept in the test furnace for $100 \mathrm{~min}$ to make $\mathrm{MC}$ of specimens achieve a stable value throughout the test process. Bending creep

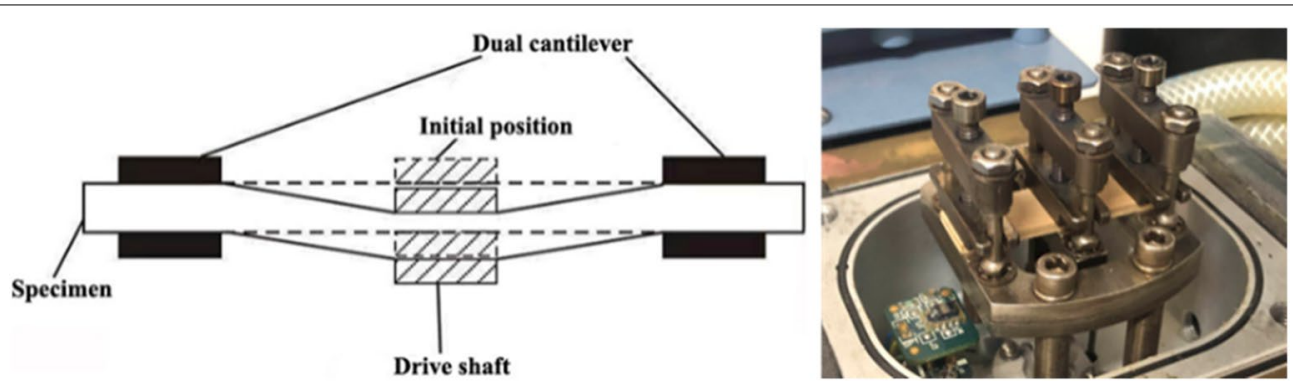

Fig. 2 Schematic diagram of double cantilever bending 
characteristics of the tested specimens were investigated under a constant stress of $5 \mathrm{MPa}$ to avoid yielding fracture of white oak specimens and further obtain more creep details of tested specimens in the investigation process in accordance with an earlier study [17]. The corresponding hold time of preset temperature and $\mathrm{RH}$ was $45 \mathrm{~min}$. Additionally, the static bending stress was preset to $0.01 \mathrm{~N}$ to fix the white oak specimen on double cantilever fixture. The recovery time was $45 \mathrm{~min}$ with the removal of $5 \mathrm{MPa}$ constant stress [17]. Data of bending creep characteristics were collected by a DMA and recorded by a computer. The corresponding data graph of strain changes in percent as a function of time was generated under the creep model. Three adjacent repetitions for each type of tested specimen were prepared for the creep measurement.

\section{Model description Burger model}

A gradual increase is observed to wood strain with increase in application time under a constant external stress due to its obvious viscoelastic behavior of wood. The establishment of mathematical model plays a more and more important role in investigation and prediction of wood creep behaviors [18]. From previous studies, the four-element Burger model connected by Maxwell model and Kelvin model in series, is a useful mechanical model that can accurately describe the creep behavior of materials. Among which, Maxwell model is used to simulate elastic and viscous strains of materials, and Kelvin model is used to simulate viscoelastic strains of materials. The constitutive equation of Burger model is $[19,20]$ :

$$
\varepsilon(t)=\sigma\left[\frac{1}{E_{0}}+\frac{1}{E_{1}}\left(1-e^{\frac{-t E_{1}}{\eta_{1}}}\right)+\frac{1}{\eta_{2}} t\right],
$$

where $\varepsilon(t)$ is the strain; $\sigma$ is the stress; $E_{0}$ is the universal elastic modulus reflects the instantaneous response (i.e., ideal elasticity); $E_{1}$ is the high elastic modulus; $\eta_{1}$ is the viscoelasticity coefficient reflects the lag elastic deformation; $\eta_{2}$ is the bulk viscosity reflects the unrecoverable deformation left in the recovery process after the removing of external forces; $t$ is the time.

According to the four-element model, the creep formula of Burger model can be simplified as follows [21]:

$$
\varepsilon(t)=p_{1}+p_{2}\left(1-e^{-p_{3} t}\right)+p_{4} t,
$$

where $\varepsilon(t)$ is the strain; $p_{1}$ is the instantaneous elastic deformation; $p_{2}$ is the delayed elastic deformation; $p_{3}$ is the bulk viscosity; $p_{4}$ is the viscosity coefficient; $t$ is the time.

\section{Five-parameter model}

Although Burger model showed obvious advantages in simulating wood creep behavior, the creep variable of wood was overestimated in the final stage predicted by Burger model. An assumption of a constant deformation rate to the viscous flow deformation of wood is applied in the simulation of Burger model, which is not consistent with the actual creep behavior of wood after the end of test [22]. Increment in the final deformation of wood is regarded as a viscous deformation, and the expression used to simulate the viscous part of wood in Burger model is a linear formula, resulting in a linear trend of the simulated strain curve as a function of time. Actually, the increase rate of viscous flow deformation of wood is non-linear. Therefore, a Fiveparameter model assuming of a non-linear increase formula of viscoelastic has been proposed to further simulate wood creep behavior by Dinwoodie et al. [23] Besides, the only difference between Burger model and Five-parameter model was the formula viscosity coefficient as illustrated in Eqs. (2) and (3). The corresponding creep formula of Five-parameter model is shown as follows:

$$
\varepsilon(t)=\beta_{1}+\beta_{2}\left(1-e^{-\beta_{3} t}\right)+\beta_{4} t^{\beta_{5}},
$$

where $\varepsilon(t)$ is the strain; $\beta_{1}$ is the instantaneous elastic deformation; $\beta_{2}$ is the delayed elastic deformation; $\beta_{3}$ is the viscoelasticity coefficient; $\beta_{4}$ is the viscosity coefficient; $\beta_{5}$ is an additional parameter, which solve the problem of viscosity part nonlinearity, and it has no practical significance; $t$ is the time.

\section{Results and discussion}

\section{Microstructure and tissue ratio of earlywood vessel belt}

The anatomical structure of white oak specimens with various distributions of earlywood vessel belt is presented in Fig. 3. As illustrated in the figure, earlywood vessel was relatively evenly distributed in the earlywood vessel belt in cross section of Specimen A, B and C. Earlywood vessel belt ratio $\left(R_{\mathrm{T}}\right)$ and earlywood vessel ratio $\left(R_{\mathrm{C}}\right)$ in Specimen $\mathrm{A}, \mathrm{B}$ and $\mathrm{C}$ are listed Table 1. It indicated that $R_{\mathrm{T}}$ in tested specimens with various distributions of earlywood vessel belt was almost the same, the corresponding values of $R_{\mathrm{T}}$ was $36.85 \pm 1.70 \%$ (Specimen A), 35.82 $\pm 1.64 \%$ (Specimen B) and $36.13 \pm 1.73 \%$ (Specimen C), respectively. As shown in Table $1, R_{\mathrm{C}}$ of Specimen A $(26.44 \pm 0.44 \%), B(24.46 \pm 0.69 \%)$ and C $(26.30 \pm 0.28 \%)$ was also consistent under different distributions of earlywood vessel belt conditions. It was noted that $R_{\mathrm{T}}$ and $R_{\mathrm{C}}$ in Specimen $\mathrm{A}, \mathrm{B}$ and $\mathrm{C}$ were the same, providing effective evidence for the reliability of 

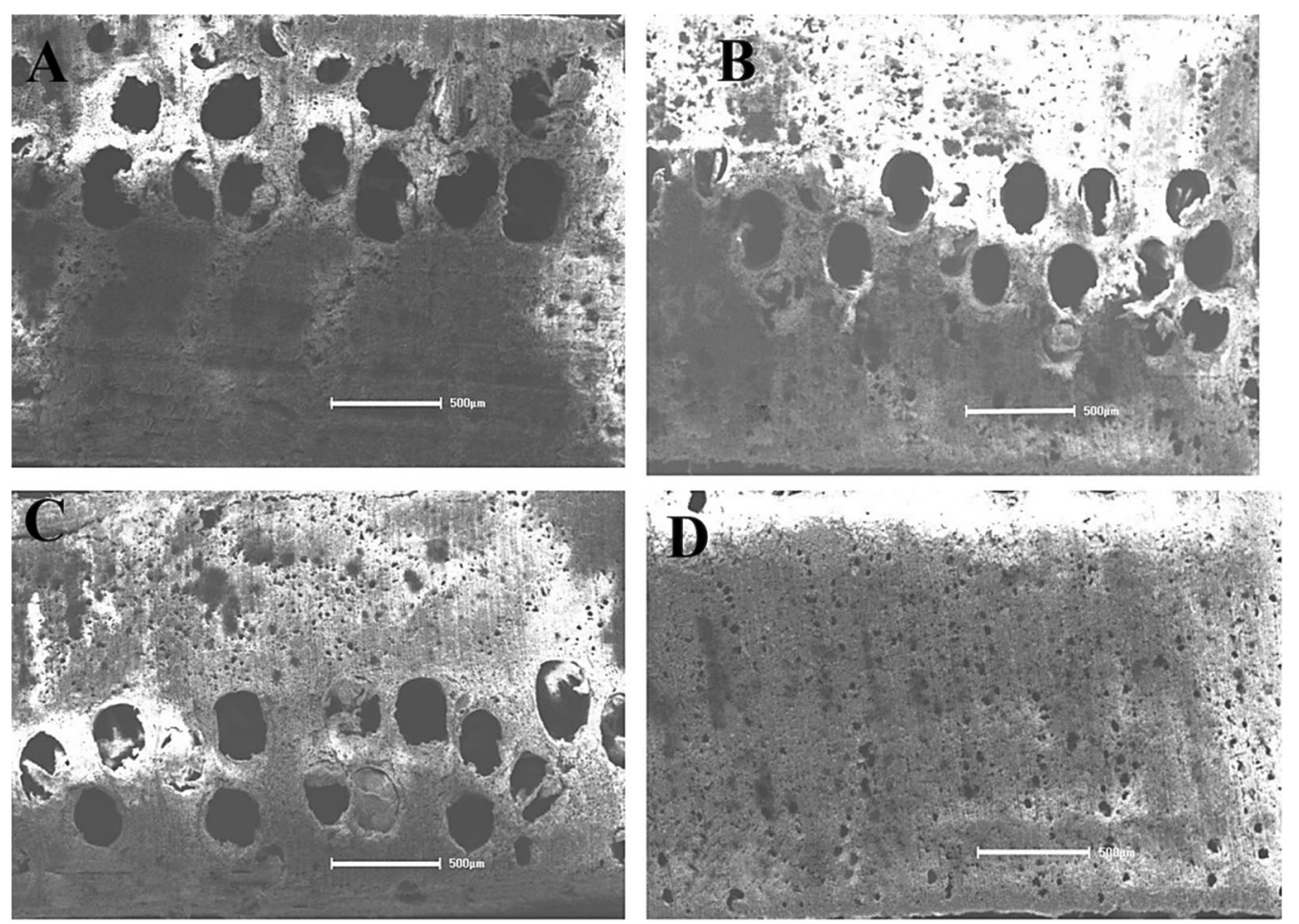

Fig. 3 Anatomy structure of white oak specimens with various distributions of earlywood vessel belt

Table 1 Tissue ratio of earlywood vessel belt $\left(R_{\mathrm{T}}\right)$ and earlywood vessel $\left(R_{C}\right)$ for the specimens with various distributions of earlywood vessel belt

\begin{tabular}{lcclll}
\hline $\begin{array}{l}\text { Specimen } \\
\text { code }\end{array}$ & \multicolumn{2}{l}{$\begin{array}{l}\text { Tissue ratio of earlywood } \\
\text { vessel belt }\left(\boldsymbol{R}_{\mathrm{T}}\right)\end{array}$} & & \multicolumn{2}{l}{$\begin{array}{l}\text { Tissue ratio of earlywood } \\
\text { vessel }\left(\boldsymbol{R}_{\mathrm{C}}\right)\end{array}$} \\
\cline { 2 - 3 } \cline { 5 - 6 } & Mean $^{\mathrm{a}} \pm \mathrm{SD}(\%)$ & $\mathrm{CV}(\%)$ & & Mean $^{\mathrm{a}} \pm \mathrm{SD}(\%)$ & $\mathbf{C V}(\%)$ \\
\hline $\mathrm{A}$ & $36.85 \pm 1.70$ & 4.63 & & $26.44 \pm 0.04$ & 0.13 \\
$\mathrm{~B}$ & $35.82 \pm 1.64$ & 4.56 & & $24.46 \pm 0.69$ & 2.8 \\
$\mathrm{C}$ & $36.13 \pm 1.73$ & 4.78 & & $26.30 \pm 0.28$ & 1.05 \\
$\mathrm{D}^{\mathrm{b}}$ & $0 \pm 0$ & 0 & & $0 \pm 0$ & 0 \\
\hline
\end{tabular}

${ }^{\mathrm{a}}$ Mean is for repeated specimens. CV is coefficient of variation

${ }^{\mathrm{b}}$ White oak specimen without earlywood vessel belt (the control group)

data obtained in this study. Therefore, the number and distribution state of earlywood vessel belt in the tested specimens were relatively consistent to obtain more useful details on creep behavior of white oak specimens with different distributions of earlywood vessel belt.

\section{Effects of test temperature}

Creep strain curves of white oak specimens at different temperatures are presented in Fig. 4. Results revealed that creep strain of white oak specimens strongly depend on test temperature. As can be seen in Fig. 4, a gradual increase in 45-min strain was observed with increase in test temperature. An obvious increment was generated to creep strain with increase in temperature from 40 to $60{ }^{\circ} \mathrm{C}$, and the increment in creep strain was increased further with increase in temperature from 60 to $80{ }^{\circ} \mathrm{C}$ in the initial $45 \mathrm{~min}$. These notable changes are mainly caused by softening of cell wall matrix, which becomes significant with temperature changes and water sorption $[23,24]$. It was also found that the creep strain of Specimen A, B and C increased to the maximum value, followed by a slight reduction with the further increase in time at 20 and $40{ }^{\circ} \mathrm{C}$, and the corresponding ultimate residual creep strain values were negative. However, the creep strain was observed to increase rapidly to the maximum value and then followed by a slow increase with the further increase of the temperature to 60 and $80{ }^{\circ} \mathrm{C}$, the corresponding ultimate residual strain values were positive. Furthermore, the ultimate residue creep strain at $80^{\circ} \mathrm{C}$ was nearly double or triple higher than that at $60^{\circ} \mathrm{C}$. For the white oak specimens with various distribution of earlywood vessel belt, an obvious creep phenomenon was generated with the further increase in temperature to $80{ }^{\circ} \mathrm{C}$. This may be due to the transient elastic response of wood under small loads provided by the elastic deformation of micro-fibrils and cells. The thermal expansion of micro-fibrils was increased with increase in test 

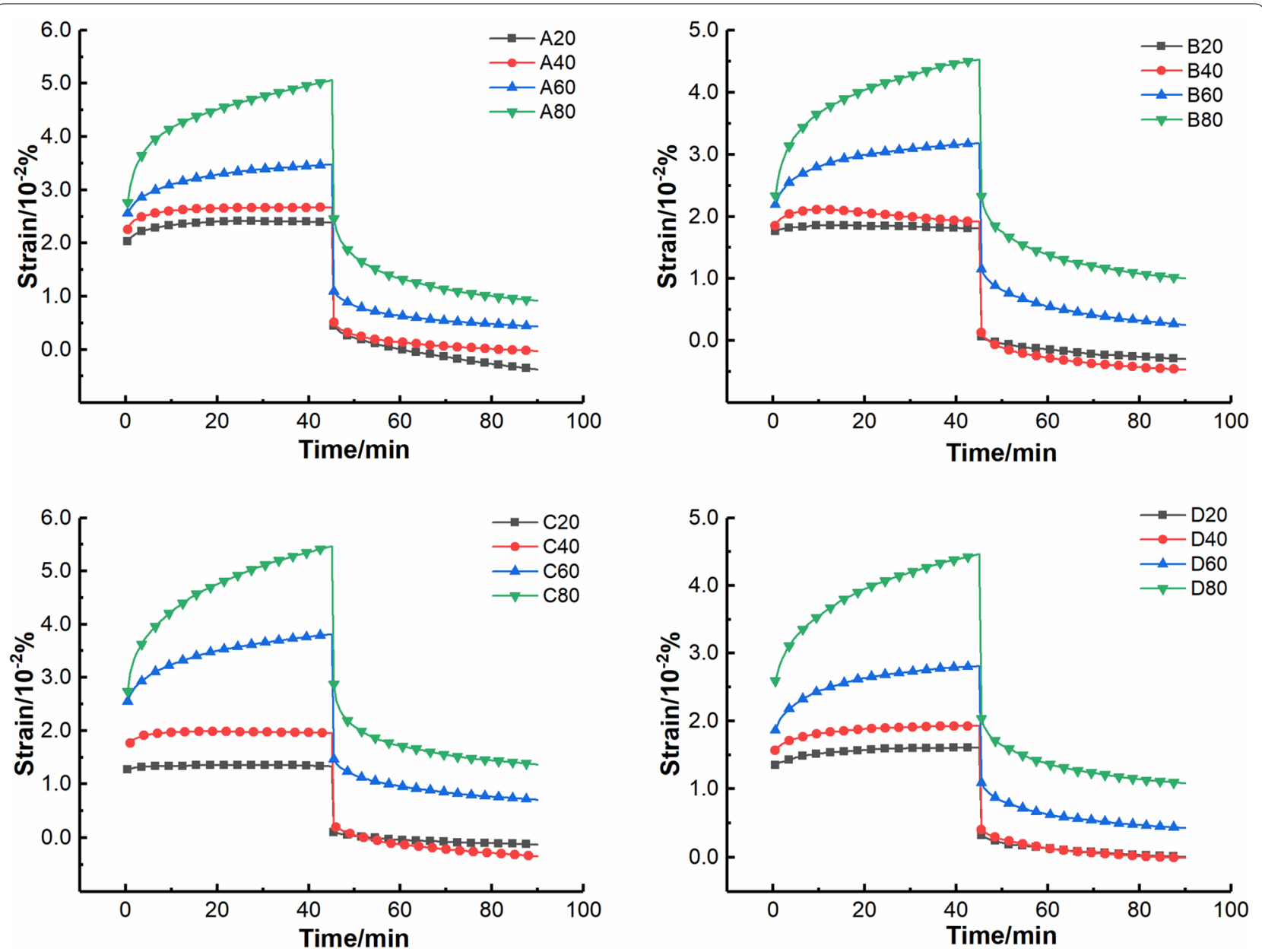

Fig. 4 Creep behaviors of the specimens at different temperatures

temperature, resulting in the changes in lattice internal of cellulose and further reduction of cohesion among cellulose molecules, and further promoting the softening of cellulose in wood [25]. Moreover, mechanical strength of white oak wood was sharply decreased with the further increasing temperature to $80^{\circ} \mathrm{C}$ or above as expected.

Figures 5 and 6 show instantaneous strain and 45-min strain of white oak specimens at different temperatures and distributions of earlywood vessel belt. An obvious increment in instantaneous strain and 45-min strain of white oak specimens was observed with the increase of temperature from 20 to $80{ }^{\circ} \mathrm{C}$. Activation energy required for the moving unit was increased with increase in temperature, and the corresponding intermolecular interaction force was decreased, resulting in the increase in intermolecular distance and moving unit activity space. Therefore, an obvious change in creep strain of the tested specimens was expected [26, 27]. In addition, it was reported that the glass transition temperature of lignin in general wet wood ranges from

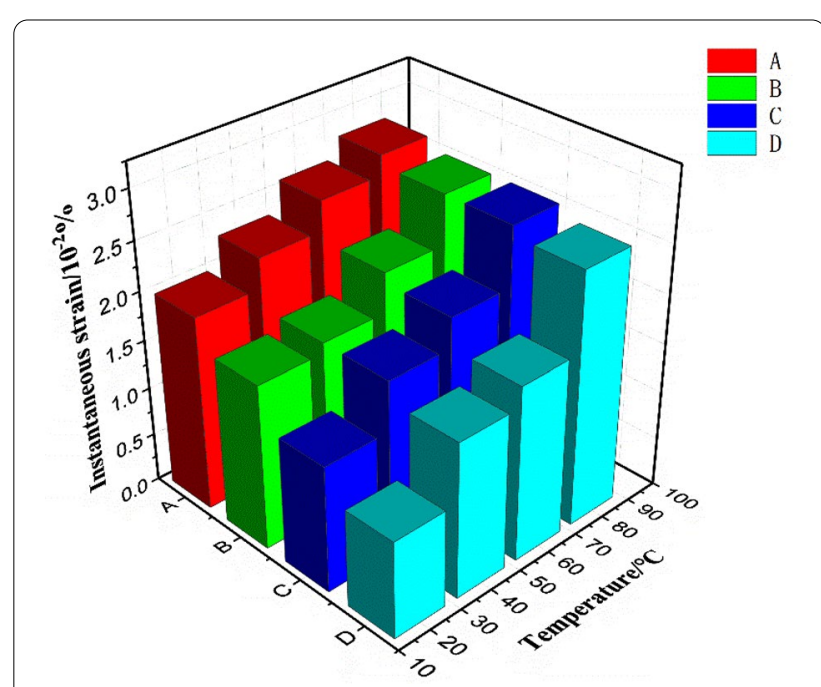

Fig. 5 Instantaneous strain of white oak specimens at different temperatures and distributions of earlywood vessel belt 


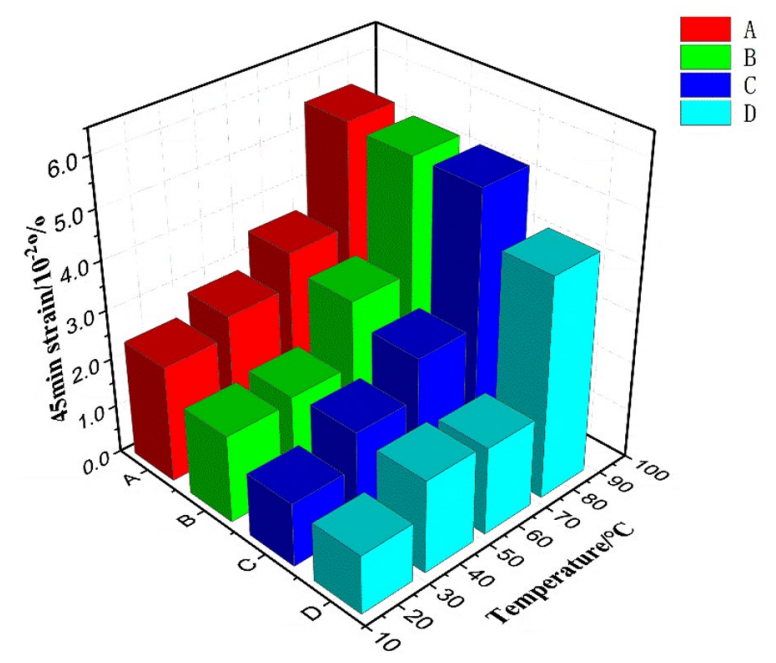

Fig. 6 45-min strain of white oak specimens at different temperatures and distributions of vessel layer

72 to $128{ }^{\circ} \mathrm{C}$ [17]. The state of lignin molecular chain segment was changed from the frozen state to a moving state, and the glass transition of the specimens was reached at $80^{\circ} \mathrm{C}$. In addition to the expansion of molecular occupation volume, expansion of free volume of the lignin in wood occurs with the increase of temperature [28]. Therefore, movement space of motion unit is increased greatly, so did the creep deformation of the specimens. Moreover, the difference between energy elasticity and entropy elasticity may also result in the difference in creep behavior of tested specimens at different earlywood vessel distributions.

It was also noted that creep strain of Specimen $D$ was smaller than that of Specimen A, B and C, which is related to the existence and distribution of earlywood vessel belt and various tested temperatures. An obvious creep phenomenon occurred in the specimens with various distributions of earlywood vessel belt and the corresponding strain obviously increased with the further increase of temperature to $80{ }^{\circ} \mathrm{C}$. Energy acquired for the extension or sliding of molecular chain in wood cell wall was increased with increase in testing time, leading to a violent molecular movement and the break of chemical bond among molecules. There was an increase in the fluidity and ductility of molecular chain $[29,30]$, an increase in the creep rate and creep compliance finally as expected [31,32]. Additionally, most of wood cells are arranged along the axial direction, which determines that the axial creep compliance of wood is generally smaller than that of the radial creep compliance [8]. However, the radial wood ray cells have the effect of strengthening on the radial orientation in comparison with that of the tangential direction arranged along the thickness direction, resulting in a greater radial creep compliance [24,33].

\section{Effects of existence and distribution of earlywood vessel belt}

Creep strain curves of white oak specimens with various earlywood vessel belt distributions are illustrated in Fig. 7. It was found that creep strain of white oak specimens was obviously affected by the existence and various distributions of earlywood vessel belt. For different temperature values chosen, the 45-min strain of Specimen A, $B$ and $C$ was decreased with increase in distance between earlywood vessel belt and stress acting surface. Creep strain of Specimen A, B and C was greater than that of Specimen D at the same tested temperature. However, the 45-min strain of Specimen A and B was decreased with increase in distance between earlywood vessel belt and stress acting surface, and increased with the further increasing distance between earlywood vessel belt and stress acting surface (Specimen $\mathrm{C}$ ) at $80{ }^{\circ} \mathrm{C}$. It also indicated that creep strain of Specimen A was slightly greater than that of Specimen $C$, and creep strain curves of Specimen $\mathrm{B}$ and $\mathrm{D}$ almost coincided with the 45-min strain. As described in the stress concentration problem of holes or circular holes in elasticity on the basis of Lamet equation of elasticity, stress at the edge of hole is much greater than that without hole, and it will also be greater than the stress slightly away from the hole as an elastic body with small holes subjected to external stress [34]. The effects of stress on circular hole or circular channel were decreased with increase in distance between the circular hole or circular channel and stress in accordance with the SaintVenant's principle of elastic mechanics. The stress concentration phenomenon of earlywood vessel was more obvious with increase in distance between the stress and earlywood vessel as the specimens subjected to an external stress. It was also observed that the earlywood vessel was compressed, bent, and deformed to a certain extent, which led to a brittle fracture of wood.

As can also be seen in Figs. 5 and 6, instantaneous strain and 45-min strain of the specimens were obviously decreased with the enlargement of distance between earlywood vessel belt and stress acting surface at 20, 40 and $60{ }^{\circ} \mathrm{C}$. A reduction of instantaneous strain and 45-min strain of Specimen C was nearly $40 \%$ and $50 \%$ in comparison with Specimen A at $20{ }^{\circ} \mathrm{C}$. Moreover, the reduction of instantaneous strain was decreased by 18.2 and $19.2 \%$ with the further increase of temperature to 40 and $60{ }^{\circ} \mathrm{C}$, respectively, and that of 45-min strain was decreased by 24.0 and $17.1 \%$, respectively. However, instantaneous strain and 45 -min strain only slightly decreased at $80{ }^{\circ} \mathrm{C}$, and the corresponding difference between Specimen A 

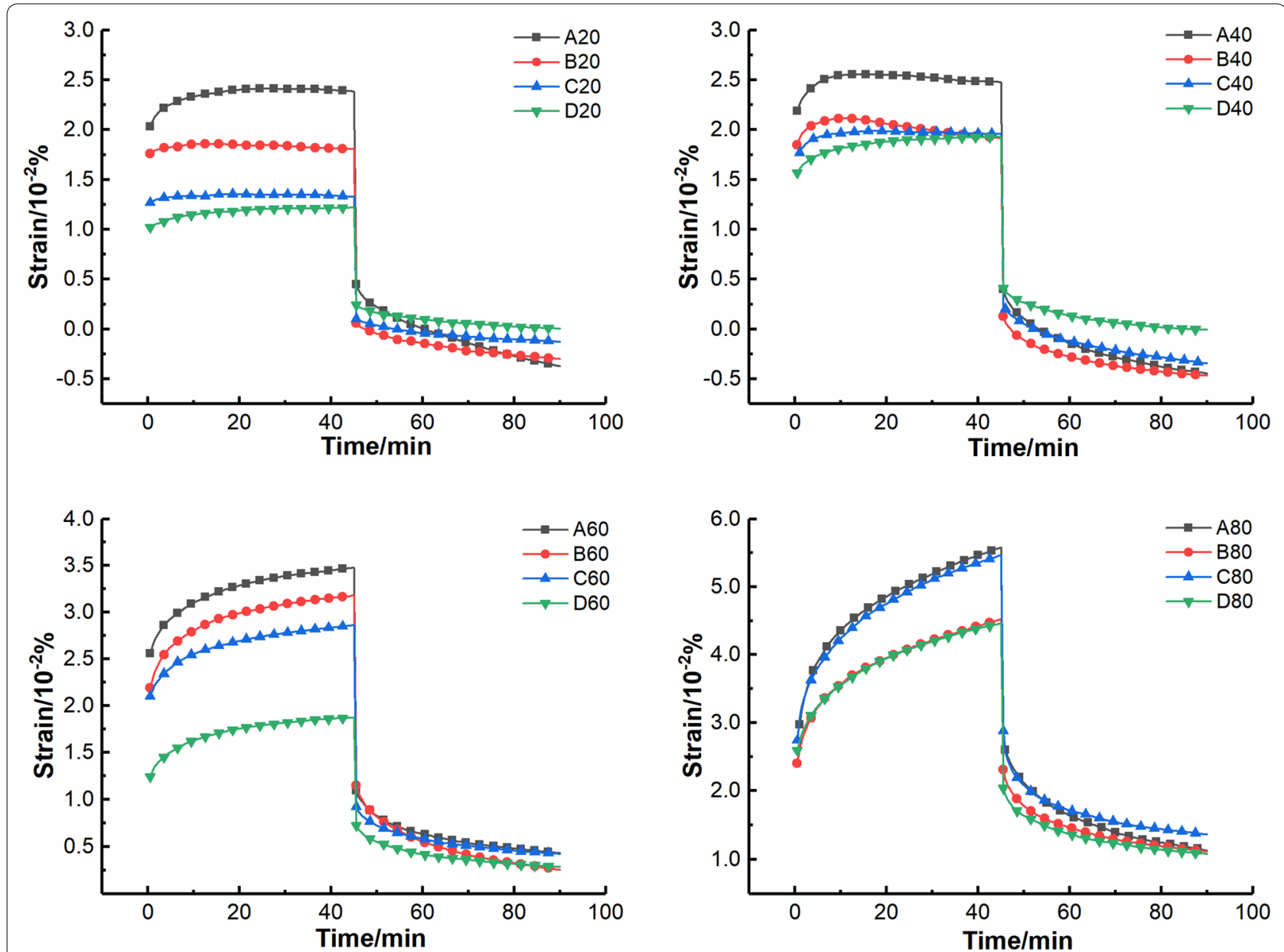

Fig. 7 Creep behaviors of the specimens with various distributions of earlywood vessel belt

and $C$ was 10.0 and $11.8 \%$, respectively. This may be due to the generation of slippage among micro-fibrils in the earlywood vessel cell wall of tested specimens under the action of stress, the wall layer of earlywood vessel cell wall to fold. Besides, the compression surface of specimen was folded, and the tension surface was wrinkled under the action of bending moment [3]. The longitudinal bending tensile strength of wood is generally greater than the compressive strength as known from previous researches. The effect of stress on vessel cell increases with reduction in distance between earlywood vessel belt and stress acting surface, the tensile and compressive effect were increased as the specimens were bent longitudinally, leading to a tendency to deform easily and the creep is more distinct in white oak specimen. Obvious creep phenomenon occurred in the tested specimens at $80{ }^{\circ} \mathrm{C}$. While cellulose and hemicellulose will be softened at high temperature, simultaneously, the lignin will undergo glass transition. The volume expansion of lignin (i.e., occupied volume expansion and free volume expansion) will lead to an obvious increase in activity space of moving unit with increase in temperature, which is shown as the increase of creep deformation [17], and the effect of earlywood vessel belt on creep strain of white oak specimens declined. Obvious creep phenomenon was generated in the specimens and their mechanical strength was sharply decreased with the further increasing temperature to $80^{\circ} \mathrm{C}$ or above. Therefore, it was concluded that the existence and distribution of earlywood vessel belt affects the creep strain of white oak specimens obviously.

It was also found that creep phenomenon of white oak specimens was not obvious at 20 and $40{ }^{\circ} \mathrm{C}$, the corresponding creep curves of white oak specimens were intensified, and creep effect was more obvious with the further increasing temperature from 40 to $60{ }^{\circ} \mathrm{C}$ and $80{ }^{\circ} \mathrm{C}$, respectively. Increasing rate of creep strain for white oak samples at $80{ }^{\circ} \mathrm{C}$ was greater than that of the creep strain tested at 20,40 and $60{ }^{\circ} \mathrm{C}$. It was also noted that obvious creep phenomenon occurred in all the 
tested specimens. Difference of creep strain among the tested specimens with various distribution of earlywood vessel belt was limited, and the effect of earlywood vessel belt distribution on creep strain of white oak specimen was not obvious. Therefore, it was concluded that the white oak is not suitable for application in environments with temperature above $80^{\circ} \mathrm{C}$. The reason was that most of the cellulose segments in wood exist in crystalline state, a few in amorphous form, both lignin and hemicellulose exist in amorphous form. Free volume of molecules is increased, and the movement is accelerated especially for the amorphous polymers such as lignin and hemicellulose with the rise in temperature, leading to a sharp increase in wood creep $[35,36]$.

\section{Comparative numerical modeling results of Burger and Five-parameter model}

Comparison between fitting results of Burger and Fiveparameter model is presented in Tables 2 and 3, respectively. The fitting results revealed that instantaneous elastic deformation $\left(\beta_{1}\right)$ of Five-parameter model was basically consistent with that of Burger model $\left(P_{1}\right)$. Both

Table 2 Fitting parameters of Burger model for the specimens at different temperatures

\begin{tabular}{|c|c|c|c|c|c|c|}
\hline Temperature $\left({ }^{\circ} \mathrm{C}\right)$ & Sample code & $P_{1}$ & $P_{2}$ & $P_{3}$ & $P_{4}$ & $R^{2}$ \\
\hline \multirow[t]{4}{*}{20} & A & 0.02046 & 0.00395 & 0.14802 & $-1.04 \times 10^{-5}$ & 0.98981 \\
\hline & B & 0.01759 & 0.00135 & 0.17429 & $-1.99 \times 10^{-6}$ & 0.96644 \\
\hline & C & 0.01283 & 0.00107 & 0.10117 & $-1.21 \times 10^{-5}$ & 0.90926 \\
\hline & D & 0.01018 & 0.00176 & 0.12493 & $5.96 \times 10^{-5}$ & 0.99999 \\
\hline \multirow[t]{4}{*}{40} & A & 0.02150 & 0.00464 & 0.25875 & $-3.15 \times 10^{-5}$ & 0.99562 \\
\hline & B & 0.01889 & 0.00366 & 0.34299 & $-7.47 \times 10^{-5}$ & 0.99832 \\
\hline & C & 0.01723 & 0.00278 & 0.26179 & $-9.35 \times 10^{-6}$ & 0.98840 \\
\hline & D & 0.01658 & 0.00255 & 0.15264 & $8.14 \times 10^{-6}$ & 0.99999 \\
\hline \multirow[t]{4}{*}{60} & A & 0.02568 & 0.00624 & 0.14331 & $6.52 \times 10^{-5}$ & 0.99791 \\
\hline & B & 0.02187 & 0.00680 & 0.17319 & $7.20 \times 10^{-5}$ & 0.99781 \\
\hline & C & 0.02090 & 0.00494 & 0.16969 & $6.36 \times 10^{-5}$ & 0.99865 \\
\hline & D & 0.01247 & 0.00452 & 0.14327 & $4.07 \times 10^{-5}$ & 0.99811 \\
\hline \multirow[t]{4}{*}{80} & A & 0.02780 & 0.01526 & 0.19556 & $2.90 \times 10^{-4}$ & 0.99877 \\
\hline & B & 0.02386 & 0.01132 & 0.20024 & $2.28 \times 10^{-4}$ & 0.99854 \\
\hline & C & 0.02263 & 0.01408 & 0.17289 & $2.82 \times 10^{-4}$ & 0.99693 \\
\hline & D & 0.02081 & 0.01018 & 0.14403 & $1.93 \times 10^{-4}$ & 0.99861 \\
\hline
\end{tabular}

Table 3 Fitting parameters of Five-parameter model for the specimens with various distributions of earlywood vessel belt

\begin{tabular}{|c|c|c|c|c|c|c|c|}
\hline Temperature $\left({ }^{\circ} \mathrm{C}\right)$ & Sample code & $\beta_{1}$ & $\beta_{2}$ & $\beta_{3}$ & $\beta_{4}$ & $\beta_{5}$ & $R^{2}$ \\
\hline \multirow[t]{4}{*}{20} & A & 0.02009 & -1.66751 & 0.00178 & 0.00386 & 0.92857 & 0.99488 \\
\hline & B & 0.01746 & -1.03732 & 0.00166 & 0.00205 & 0.94681 & 0.96900 \\
\hline & C & 0.01274 & -0.93413 & 0.00071 & 0.00082 & 0.94286 & 0.92799 \\
\hline & D & 0.01002 & -1.95205 & 0.00097 & 0.00224 & 0.95604 & 0.99811 \\
\hline \multirow[t]{4}{*}{40} & A & 0.02127 & -1.68162 & 0.00288 & 0.00621 & 0.92280 & 0.99029 \\
\hline & B & 0.01901 & -1.57371 & 0.00286 & 0.00554 & 0.92944 & 0.99029 \\
\hline & C & 0.01710 & -1.00274 & 0.00396 & 0.00403 & 0.94384 & 0.99799 \\
\hline & D & 0.01632 & -0.78150 & 0.00219 & 0.00233 & 0.91761 & 0.99818 \\
\hline \multirow[t]{4}{*}{60} & A & 0.02501 & -1.40544 & 0.00237 & 0.00484 & 0.90517 & 0.99930 \\
\hline & B & 0.02113 & -1.01594 & 0.00339 & 0.00533 & 0.88446 & 0.99900 \\
\hline & C & 0.02044 & -1.70978 & 0.00223 & 0.00511 & 0.92322 & 0.99920 \\
\hline & D & 0.01202 & -1.87526 & 0.00178 & 0.00440 & 0.92936 & 0.99930 \\
\hline \multirow[t]{4}{*}{80} & A & 0.02658 & 0.00261 & 0.35869 & 0.00755 & 0.31304 & 0.99999 \\
\hline & B & 0.02295 & -0.28655 & 0.00833 & 0.00657 & 0.74727 & 0.99942 \\
\hline & C & 0.02303 & -0.04828 & 0.01365 & 0.00820 & 0.49506 & 0.99928 \\
\hline & D & 0.02107 & -0.32570 & 0.00530 & 0.00474 & 0.77182 & 0.99969 \\
\hline
\end{tabular}


of instantaneous elastic deformation coefficient in Burger model $\left(P_{1}\right)$ and Five-parameter model $\left(\beta_{1}\right)$ of Specimen $\mathrm{A}, \mathrm{B}$ and $\mathrm{C}$ were increased with increase in temperature from $20{ }^{\circ} \mathrm{C}$ to $80{ }^{\circ} \mathrm{C}$. However, the corresponding values of instantaneous elastic deformation coefficient for Burger model $\left(P_{1}\right)$ and Five-parameter model $\left(\beta_{1}\right)$ were decreased with the enlargement of distance between earlywood vessel belt and stress acting surface. It was also noted that the correlation coefficient $\left(R^{2}\right)$ related to Fiveparameter model was greater than that of Burger model under the same test condition (Tables 2 and 3). The reason was that creep variable of wood was overestimated in the ultimate stage predicted by Burger model due to a constant viscous deformation rate assumed in the last stage of creep behavior, which is inconsistent with the actual creep behavior of wood and the increment of ultimate deformation belongs to viscous deformation [37]. The expression used in the simulation of viscosity part in Burger model is a linear formula, resulting in a linear change rule of simulated curve as a function of time [18, 20]. Nevertheless, the fifth parameter $\left(\beta_{5}\right)$ was introduced into Five-parameter model, which makes the last stage of creep show a non-linear growth trend. This is evidently consistent with the actual creep deformation change [38]. Therefore, Five-parameter model exhibits obvious advantage in predicting and describing creep characteristics of white oak wood due to the introduction of a non-linear growth expression of creep strain which is more consistent with the actual creep process of wood.

\section{Effects of test temperature on fitting results of creep model} parameters

Comparison between the model simulation and experimental points of white oak specimens at different temperatures is presented in Fig. 8 (BM is for the simulation of Burger model and FM for the simulation Fiveparameter model). It indicated that the creep curves of specimens at different temperatures can be accurately modeled by Burger model and Five-parameter model. Besides, results related to Burger model are listed in Table 2. Instantaneous elastic deformation viscosity coefficients $\left(P_{1}\right)$ of Specimen A, B and C were increased with

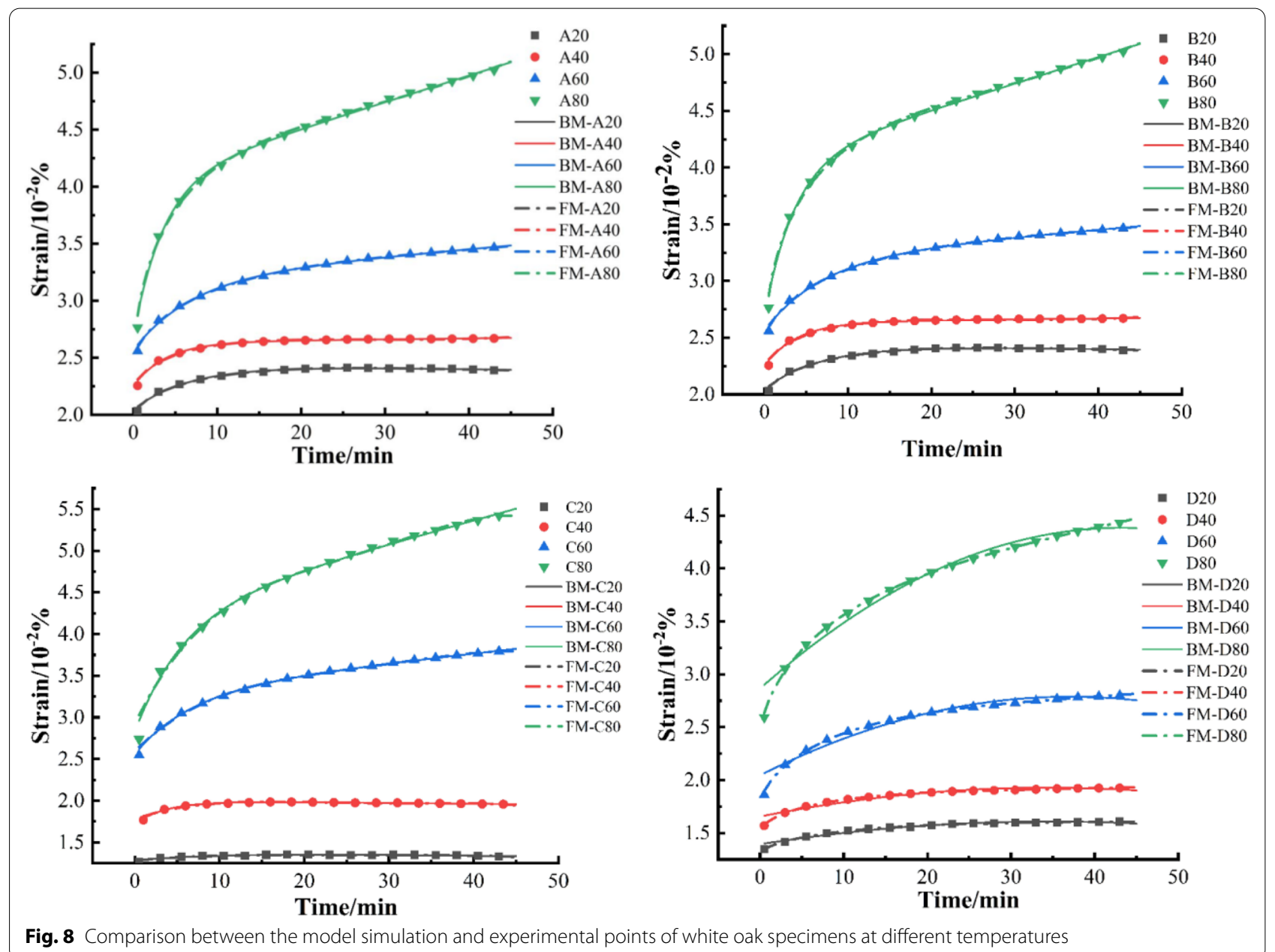


increase in tested temperature as illustrated in Table 2. This is mainly because instantaneous elastic response of wood is generated as the elastic deformation of microfibrils and the corresponding cells under a small external load. Thermal expansion was generated in the microfibrils with increase in test temperature, resulting in the lattice spacing change of cellulose. The decrease of force among the cellulose molecules results in the softening of cellulose [39]. Instantaneous elastic deformation $\left(P_{1}\right)$ of Specimen $D$ was decreased with the increase of temperature from 20 to $60^{\circ} \mathrm{C}$, and rapidly increased as a function of time under the constant stress of $5 \mathrm{MPa}$ with further increasing temperature to $80{ }^{\circ} \mathrm{C}$. For the data related to Five-parameter model shown in Table 3, instantaneous elastic deformation $\left(\beta_{1}\right)$ of Specimen $\mathrm{A}, \mathrm{B}$ and $\mathrm{C}$ were like the fitting results from Burger model. However, the fitted results of Specimen D were not. The correlation coefficient $\left(R^{2}\right)$ fitted using Five-parameter model was greater than that of the Burger model under the same temperature condition (Tables 2 and 3).

\section{Effects of existence and distribution of earlywood vessel} belt on the fitting results of creep model parameters

Comparison between the model simulation and experimental points of white oak specimens with various distributions of earlywood vessel belt is illustrated in Fig. 9 (BM is for the simulation of Burger model and FM for the simulation Five-parameter model). It indicated that the creep curves of specimens with various distributions of earlywood vessel belt can be accurately modeled by Burger model and Five-parameter model. As shown in Table 2, it indicated that instantaneous elastic deformation $\left(P_{1}\right)$ of Specimen $\mathrm{A}, \mathrm{B}$ and $\mathrm{C}$ was decreased with increase in distance between earlywood vessel belt and stress acting surface at 20,40 and $60{ }^{\circ} \mathrm{C}$. It has been reported that vessel cells are widely distributed in hardwood such as oak, elm, ash and so on. The reinforcement effect of earlywood vessel is weakened with increase in distance between earlywood vessel belt and the stress acting surface in the bending process, the creep effect offset by earlywood vessel belt is
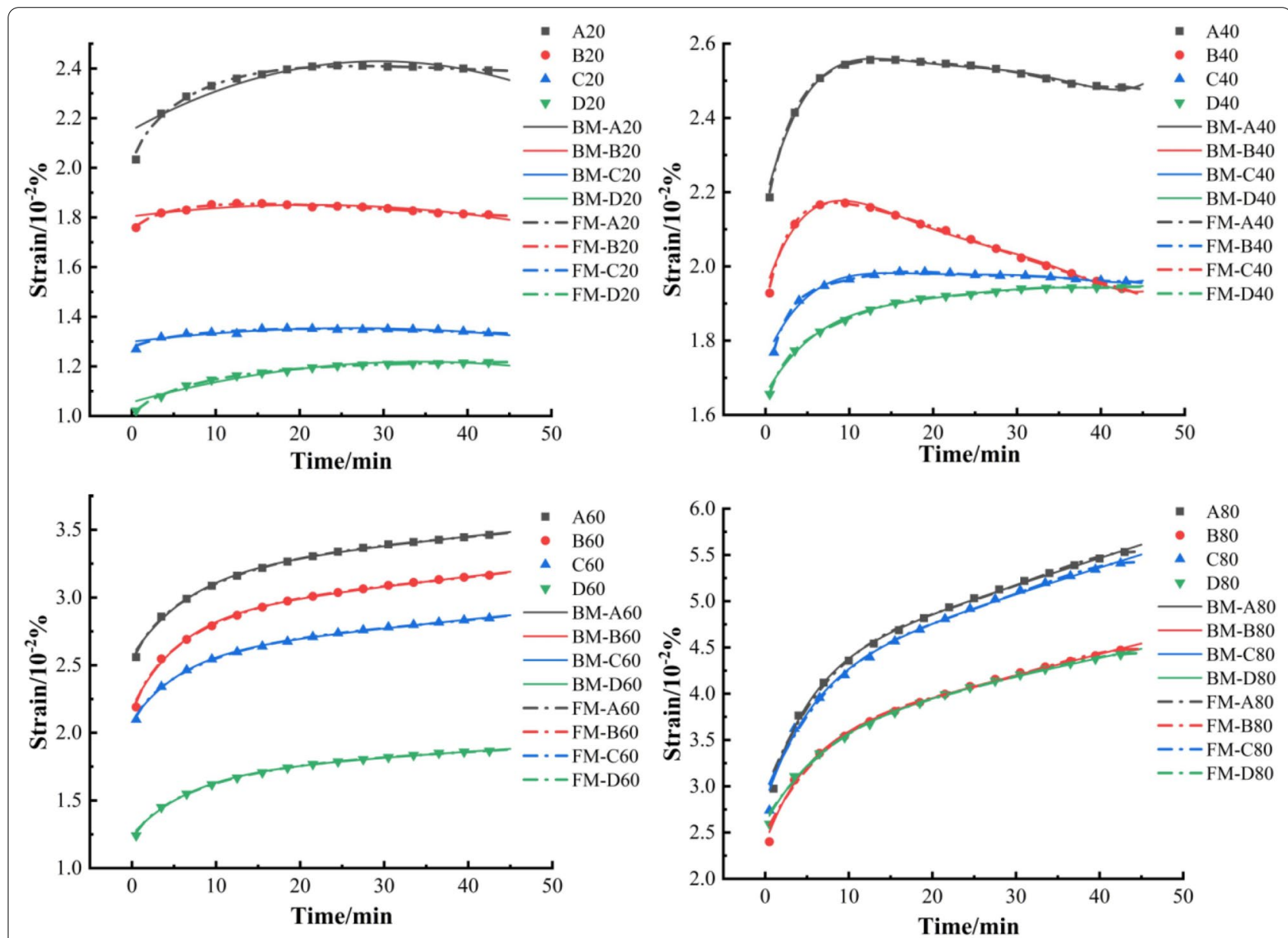

Fig. 9 Comparison between the model simulation and experimental points of white oak specimens with various distributions of earlywood vessel belt 
also reduced [34]. The counteraction effect of earlywood vessel belt on creep behavior is also weakened at $80{ }^{\circ} \mathrm{C}$ and the effect of temperature on wood creep behavior was more remarkable. Instantaneous elastic deformation $\left(P_{1}\right)$ of Specimen $\mathrm{D}$ was greater than that of Specimen A, B and C at $20{ }^{\circ} \mathrm{C}$ and it became smaller with further increase in temperature to 40,60 and $80{ }^{\circ} \mathrm{C}$. In addition, the variation rule of instantaneous elastic deformation $\left(\beta_{1}\right)$ of Specimen $A, B$ and $C$ using Five-parameter model shown in Table 3 was similar with that of Burger model. Moreover, the correlation coefficient $\left(R^{2}\right)$ fitted using Five-parameter model was greater than that of Burger model under the same distribution of earlywood vessel belt condition (Tables 2 and 3).

\section{Conclusion}

This work systematically investigated the effects of existence and distribution of earlywood vessel belt on creep behavior of white oak under the double cantilever bending condition. Results revealed that existence and distribution of earlywood vessel belt significantly affected creep behavior of white oak. Instantaneous strain and the 45-min strain of white oak specimens were decreased with increase in distance earlywood vessel belt and stress acting surface and increased with increase in temperatures. A counteraction effect was obtained in creep behavior of white oak due to the existence of earlywood vessel belt and decreased with increase in distance between earlywood vessel belt and stress acting surface and temperature. Both Burger model and Five-parameter model can predict the effects of temperature, existence and distribution of earlywood vessel belt on creep behavior of wood. Moreover, Five-parameter model showed a better fitting effect than Burger model according to the $R^{2}$ value. It was concluded that the introduction of a non-linear creep strain growth expression exhibited greater agreement with the experimental data of creep behavior of wood.

\footnotetext{
Abbreviations

$\varepsilon(t)$ : The strain of white oak specimen; $t$ : Time; $\sigma$ : Stress; $E_{0}$ : The universal elastic modulus reflects the instantaneous response (i.e., ideal elasticity); $E_{1}$ : The high elastic modulus; $\eta_{1}$ : The viscoelasticity coefficient reflects the lag elastic deformation; $\eta_{2}$ : The bulk viscosity reflects the unrecoverable deformation left in the recovery process after the removing of external forces; $p_{1}$ : The instantaneous elastic deformation in Burger model; $p_{2}$ : The delayed elastic deformation in Burger model; $p_{3}$ : The bulk viscosity in Burger model; $p_{4}$ : The viscosity coefficient in Burger model; $\beta_{1}$ : The instantaneous elastic deformation in Five-parameter model; $\beta_{2}$ : The delayed elastic deformation in Five-parameter model; $\beta_{3}$ : The viscoelasticity coefficient in Five-parameter model; $\beta_{4}$ : The viscosity coefficient in Five-parameter model; $\beta_{5}$ : An additional parameter, which solves the problem of viscosity part nonlinearity in Five-parameter model, and it has no practical significance; $R^{2}$ : Correlation coefficient.
}

Acknowledgements

The authors acknowledge the support of the National Engineering and Technology Research Center of Wood-Based Resources Comprehensive Utilization of Zhejiang Agriculture \& Forestry University.

\section{Authors' contributions}

$J H, Y Y$ and $Z J$ conceived and designed the experiments. YJ, YY and WZ performed the experiments and analyzed the data. JH wrote the draft of this manuscript. HC, YY and ZJ reviewed and edited the manuscript. All authors read and approved the final manuscript.

\section{Funding}

This work was financial supported by the National Natural Science Foundation of China (NO. 31670561) and Talent Startup Project of Scientific Research and Development Foundation of Zhejiang A \& F University (NO. 2020FR020).

\section{Availability of data and materials}

The datasets used and/or analyzed during the current study are available from the corresponding author on reasonable request.

\section{Declarations}

\section{Competing interests}

The authors declare that they have no competing interests.

Received: 26 April 2021 Accepted: 29 September 2021

Published online: 12 October 2021

\section{References}

1. Guessasma S, Chaunier L, Della Valle G, Lourdin D (2011) Mechanical modelling of Cereal solid foods. Trends Food Sci Tech 22(4):142-153. https://doi.org/10.1016/j.tifs.2011.01.005

2. Dubois F, Husson JM, Sauvat N, Manfoumbi M (2012) Modeling of the viscoelastic mechano-sorptive behavior in wood. Mech Time-Depend Mat 16(4):439-460. https://doi.org/10.1007/s11043-012-9171-3

3. Song KY, Wang FH, Zhu HY (2004) The techniques of Elm longitudinal compressing and bending. Sci Silvae Sin 40(2):126-130 (In Chinese)

4. Nusret A, Daniel H, Büyüksarı Ü (2018) The effect of bending parameters on mechanical properties of bent Oak wood. Eur J Wood Wood Prod 76(2):633-641. https://doi.org/10.1007/s00107-017-1162-2

5. Stevens WC (2007) Wood bending handbook: Unlock the Secrets of Curving Wood. Fox Chapel Publishing, East Petersburger

6. Diao HL, Luo JJ, Cai DX (2013) Study on the creep properties of Castanopsis Hystrix wood. J Northwest For Univ 28(2):173-177 (In Chinese)

7. Moosavi V, Eslam HK, Bazyar B, Najafi A, Talaeepoor M (2016) Bending creep behavior of Hornbeam wood. Wood Industry/Drvna Industrija 67(4):341-350. https://doi.org/10.5552/drind.2016.1609

8. Backman AC, Lindberg HKA (2001) Differences in wood material responses for radial and tangential direction as measured by Dynamic Mechanical Thermal Analysis. J Mat Sci 36(15):3777-3783. https://doi.org/ 10.1023/A:1017986119559

9. Wang D, Lin LY, Fu F (2019) The difference of creep compliance for wood cell wall CML and secondary S2 layer by nanoindentation. Mec TimeDepend Mat 25(9):1-12. https://doi.org/10.1007/s11043-019-09436-x

10. Engelund ETLS (2012) Tensile creep and recovery of Norway Spruce influenced by temperature and moisture. Holzforschung 66(8):959-965. https://doi.org/10.1515/hf-2011-0172

11. Kato Y (2013) Creep behavior of Catheter reinforced with Braids: Analytical simulation of uniaxial tension under two-stage step stress. Adv Mater Res 856:384-388

12. Wang YR, Ren HQ, Zhao RJ, Lv B (2012) Study on dry shrinkage and wet expansion of three kinds of solid wood flooring. Wood Process Machy 23:9-11. https://doi.org/10.3969/j.issn.1001-036X.2012.05.003

13. Rice RW, Youngs RL (1990) The mechanism and development of creep during drying of Red oak. Holz als Roh-und Werkstoff 48(2):73-79. https:// doi.org/10.1007/BF02610711 
14. Hoffmann P (2010) On the long-term visco-elastic behaviour of polyethylene glycol (PEG) impregnated archaeological Oak wood. Holzforschung 64(6):725-728. https://doi.org/10.1515/HF.2010.082

15. Passard J, Perré $P$ (2005) Viscoelastic behaviour of green wood across the grain. Part I. Thermally activated creep tests up to $120^{\circ} \mathrm{C}$. Ann Forest Sci 62:707-716. https://doi.org/10.1051/forest:2005067

16. Vorobyev A, Dijk NPV, Gamstedt EK (2018) Orthotropic creep in polyethylene glycol impregnated archaeological Oak from the vasa ship. Mec Time-Depend Mat 23(1):1-18. https://doi.org/10.1007/ s11043-018-9382-3

17. Wang C, Wu Q, Lin P, Yang D, Yu YM (2018) Creep characteristics of small flawless Oak wood with different texture directions. Sci Silvae Sin 54(4):76-83. https://doi.org/10.11707/j.1001-7488.20180409 (In Chinese)

18. Nguyen TT, Dao TN, Aaleti S, Hossain K, Fridely KJ (2019) Numerical model for creep behavior of axially loaded CLT panels. J Struc Eng 145(1):04011824. https://doi.org/10.1061/(ASCE)ST.1943-541X.0002219

19. Haque MN, Langrish TAG, Keep L-B, Keey RB (2000) Model fitting for visco-elastic creep of Pinus radiata during kiln drying. Wood Sci Tech 34(5):447-457. https://doi.org/10.1007/s002260000058

20. Georgiopoulos P, Kontou E, Christopoulos A (2015) Short-term creep behavior of a biodegradable polymer reinforced with wood-fibers. Compos Part B-Eng 80:134-144. https://doi.org/10.1016/j.compositesb.2015. 05.046

21. Yazdani N, Johnson E, Duwadi S (2004) Creep effect in structural composite lumber for bridge applications. J Bridge Eng 9(1):87-94. https://doi. org/10.1061/(ASCE)1084-0702(2004)9:1(87)

22. Dinwoodie JM, Higgins JA, Paxton BH, Robson DJ (1990) Creep research on particleboard-15 years work at the UK-building-research-establishment. Holz als Roh-und Werkstoff 48(1):5-10. https://doi.org/10.1007/ BF02607843

23. Hillis WE, Rozsa AN (1978) The softening temperatures of wood. Holzforschung 32(2):68-73. https://doi.org/10.1515/hfsg.1978.32.2.68

24. Zhang W, Tokumoto $M$, Takeda $T$ (2007) Effects of temperature on mechano-sorptive creep of delignified wood. J Wood Sci 53(3):187-191. https://doi.org/10.1007/s10086-006-0858-4

25. Abasolo WP, Yoshida M, Yamamoto H, Okuyama T (2002) Thermal softening of rattan canes: Influence of the hemi cellulose-lignin matrix. J Bamb Ratt 1(4):317-331. https://doi.org/10.1163/15691590260470429

26. Chang FC, Lam F (2018) Effects of temperature-induced strain on creep behavior of wood-plastic composites. Wood Sci Tech 52(5):1213-1227. https://doi.org/10.1007/s00226-018-1033-y

27. Hsieh TY, Chang FCJH (2018) Effects of moisture content and temperature on wood creep. Holzforshung 72(12):1071-1078. https://doi.org/10. 1515/hf-2018-0056

28. Furuta Y, Nakajima M, Nakanii E, Ohkoshi M (2010) The effects of lignin and hemicellulose on thermal-softening properties of water-swollen wood. Wood Sci Tech 56(3):132-138. https://doi.org/10.2488/jwrs.56.132
29. Placet V, Passard J, Perré P (2007) Viscoelastic properties of green wood across the grain measured by Harmonic tests in the range $0-95^{\circ} \mathrm{C}$ : Hardwood vs. softwood and normal wood vs. reaction wood. Holzforschung 61(5):548-557. https://doi.org/10.1515/HF.2007.093

30. Placet V, Passard J, Perré P (2008) Viscoelastic properties of wood across the grain measured under water-saturated conditions up to $135^{\circ} \mathrm{C}$ : Evidence of thermal degradation. J Mat Sci 43(9):3210-3217. https://doi. org/10.1007/s10853-008-2546-9

31. Larsen F, Ormarsson S (2014) Experimental and finite element study of the effect of temperature and moisture on the tangential tensile strength and fracture behavior in timber logs. Holzforschung 68(1):133-140. https://doi.org/10.1515/hf-2012-0149

32. Ma X, Jiang Z, Tong L, Wang G, Cheng H (2015) Development of creep models for glued laminated bamboo using the time-temperature superposition principle. Wood Fiber Sci 47(2):141-146

33. Kaboorani A, Blanchet PAL (2013) A rapid method to assess viscoelastic and mechanosorptive creep in wood. Wood Fiber Sci 45(4):370-382. https://doi.org/10.5849/forsci.11-106

34. Chen GR (2002) The elastic mechanics. Hehai University Press, Nanjing

35. Li DG (1998) A preliminary study on the bending creep properties of the Poplar wood. J Sichuan Agri Univ. https://doi.org/10.1603/j.issn.10002650.1998.01.012 (In Chinese)

36. Stanciu MD, Curtu I, Moisan E, Man D, Savin A, Dobrescu G (2015) Rheological behaviour of Curly maple wood (Acer Pseudoplatanus) used for back side of violin. Paper presented at the International Conference "Wood Science and Engineering in the Third Millennium"-ICWSE 2015, Transilvania University, Brasov, Romania, 5-7 November 2015.

37. Cai ZY, Fridley KJ, Hunt MO, Rosowsky DV (2007) Creep and creep-recovery models for wood under high stress levels. Wood Fiber Sci 34(3):425433. https://doi.org/10.1007/s00226-002-0143-7

38. Mohammadabadi M, Yadama V, Geng J (2018) Creep behavior of 3D core wood-strand sandwich panels. Holzforschung 72(6):513-519. https://doi. org/10.1515/hf-2017-0088

39. Antoniow JS, Maigret JE, Jensen C, Trannoy N, Chirtoc M, Beaugrand J (2012) Glass-transition temperature profile measured in a wood cell wall using scanning thermal expansion microscope (SThEM). Int J Thermophys 33(10-11):2167-2172. https://doi.org/10.1007/s10765-012-1313-y

\section{Publisher's Note}

Springer Nature remains neutral with regard to jurisdictional claims in published maps and institutional affiliations.

\section{Submit your manuscript to a SpringerOpen ${ }^{\circ}$ journal and benefit from:}

- Convenient online submission

- Rigorous peer review

- Open access: articles freely available online

- High visibility within the field

- Retaining the copyright to your article

Submit your next manuscript at $\boldsymbol{\nabla}$ springeropen.com 